\title{
Pesan Dakwah dalam Buku Humor Karya Mustofa Bisri
}

\author{
Lukman Ramdani*, Sitty Sumijati, dan Heny Gustini Nuraeni \\ Jurusan Komunikasi dan Penyiaran Islam, Fakultas Dakwah dan Komunikasi, \\ UIN Sunan Gunung Djati, Bandung \\ *Email:lukmanramdani01@gmail.com
}

\begin{abstract}
ABSTRAK
Penelitian ini bertujuan untuk mengetahui kategori pesan dakwah, organisasi pesan dakwah, dan imbauan pesan dakwah yang terkandung dalam buku "Dari Canda Nabi dan Sufi hingga Kelucuan Kita" Karya Mustofa Bisri. Metode yang digunakan pada penelitian ini adalah analisis isi dengan pendekatan deskriptif. Analisis ini dilakukan dengan mengidentifikasi kategori, organisasi, dan imbauan pesan pada buku dan pada tiap-tiap tema cerita. Hasil penelitian yang ditemukan menunjukan bahwa kategori pesan yang terkandung dalam buku "Dari Canda Nabi dan Sufi Hingga Kelucuan Kita" ialah pesan akidah, syariah, dan akhlak. Pesan akidah yang lebih menonjol dalam buku ini adalah pesan akidah dengan sub kategori iman kepada Allah. Organisasi pesan dalam buku ini adalah pola deduktif, induktif, kronologis, logis, topikal, dan spasial. Sedangkan organisasi pesan yang lebih dominan adalah pola kronologis. Imbauan pesan yang ada dalam buku ini adalah imbauan rasional, emosional, dan motivasional sedangkan imbauan yang lebih dominan adalah imbauan rasional dan imbauan emosional.
\end{abstract}

Kata Kunci : pesan dakwah; buku humor; Mustofa Bisri

\section{ABSTRACT}

This study aims to find out the message categories of dakwah, message organization, and appeal messages contained in the book. "Canda Nabi dan Sufi Hingga Kelucuan Kita" by Mustofa Bisri. The method used in this research is content analysis with descriptive approach. This analysis is done by identifying categories, organization, and appeal messages on the book and the message category of dakwah, organization of messages, and appeal messages on each theme of the story. The results of the research found that the categories of messages contained in the book "Canda Nabi dan Sufi Hingga Kelucuan Kita" is message Akidah, Shariah, and Akblak. The more 
prominent Message of Aqeedah in this book is the message of Aqeedah with a sub category of faith in God. The message organization in this book is a deductive, inductive, chronological, logical, topical, and spatial pattern. While the more dominant message organization is chronological pattern. The message implied in this book is a rational, emotional, and motivational appeal. A more dominant appeal is a rational appeal and an emotional appeal.

Keywords: da'wah message; bumor book; Mustofa Bisri.

\section{PENDAHULUAN}

Dakwah berasal dari bahasa arab: da'a-yad'u-da'watan yang artinya: ajakan, seruan, do'a undangan, propaganda.Secara etimologis dakwah mengandung makna yang umum dan bersifat netral yaitu segala ajakan, seruan, do'a, dan lain-lain tanpa mempertimbangkan dalam konteks apa istilah itu digunakan, artinya makna tersebut belum spesifik.

Adapun untuk lebih mengetahui makna dakwah lebih spesifik bisa dilihat secara istilah. Dakwah secara istilah dapat didefinisikan sebagai ajakan kepada umat manusia menuju jalan Allah, baik secara lisan, tulisan maupun perbuatan, dengan tujuan agar mereka mendapatkan petunjuk hingga manusia mampu merasakan kebahagiaan dalam hidupnya, baik di dunia dan di akhirat (Tajiri, 2015: 16).

Tujuan dakwah yang dijelaskan oleh Taufik (2013: 8) ialah mewujudkan kesejahteraan dan kebahagiaan di dunia maupun di akhirat dengan mendatangkan kesejahteraan dan kebahagiaan dengan jalan yang diridhai Allah. Dari tujuan dakwah untuk kesejahteraan dan kebahagian di dunia dan di akhirat, maka dakwah islamiyah menjadi keharusan bagi manusia, sebagaimana yang telah termaktub dalam Al-Qur'an Surat AliImron Ayat 104: "Dan hendaklah di antara kamu ada segolongan orang yang menyeru kepada kebajikan, menyuruh kepada yang ma'ruf dan mencegah dari yang munkar; merekalah orang-orang yang beruntung” (Departemen Agama RI, 2004: 63).

Dakwah bukan hanya diatas mimbar (lisan), bisa juga dilakukan melalui tulisan. Dakwah dengan tulisan bisa dalam bentuk surat kabar, koran, majalah, buku cerita, cerita pendek, novel, dan juga artikel. Seiring dengan berkembangnya zaman banyak juga yang berdakwah melalui tulisan di internet.

Dakwah melalui tulisan ialah proses menyampaikan dakwah yang gagasan atau materi dakwahnya berupa huruf-huruf yang diolah menjadi 
kata dan digabung menjadi kalimat serta disusun paragraf hingga menjadi topik tertentu. Kelebihan dari dakwah melalui tulisan yakni akan terus tersurat dan bisa dibaca kembali di suatu hari kemudian (Kusnawan, 2016: 15).

Para penceramah (da'i) banyak juga yang memilih berdakwah melalui tulisan dengan alasan penjelasannya lebih mendalam dan bisa menyebarkan pemikiran dan ajaran Islam dalam bentuk tulisan-tulisan yang mudah diperoleh oleh semua orang baik dalam media cetak maupun internet. Rakhmat (1998: 2) mengatakan: "verba valent, scripta manent" yang artinya, ucapan bisa hilang tulisan akan tetap abadi. Dari sana terlihat bahwa dakwah melalui tulisan memiliki banyak kelebihan dibandingkan dakwah dalam bentuk lain.

Buku dapat menambah wawasan manusia karena terdapat informasi-informasi, bisa juga menghibur, mengunggah emosi dan membentuk hingga mengubah pola pikir seseorang. Buku merupakan sarana membagi ilmu dari seorang ke orang lain. Dalam dunia pendidikan buku sangat berperan penting dalam meningkatkan intelektualitas seseorang.

Orang besar banyak yang terlahir dari antusiasnya dalam membaca buku. Ulama, dokter, sejarawan, politikus, insyinyur, maupun para intelektual pasti menyempatkan untuk membaca buku disetiap harinya. Banyak sumbangsih yang diberikan oleh buku demi perkembangan dan kemajuan ilmu pengetahuan maupun manusia.

Membaca merupakan jendela pengetahuan. Dengan membaca buku seorang yang tidak tahu menjadi tahu, dan yang sudah tahu bisa lebih tahu akan pengetahuan. Seiring dengan perkembangan internet yang sangat pesat, namun buku masih sangat berperan penting dalam dunia pendidikan maupun dalam kehidupan manusia.

Buku merupakan salah satu media dakwah tulisan yang efektif untuk menyampaikan pesan-pesan dakwah kepada pembaca. Dari sana diperlukan inovasi dan kreatifitas penulis dalam membuat buku yang menarik juga mempunyai pesan dakwah.

Dalam bukunya yang berjudul "Dari Canda Nabi \& Sufi sampai Kelucuan Kita" Mustofa Bisri menyampaikan humor-humor yang bisa menggunggah hati pembaca agar menjadi pribadi yang lebih baik. Kejelian penulis dalam membuat humor, sehingga cerita dan pesan yang ingin penulis sampaikan bisa diterima dengan baik oleh pembaca. 
Maka dari itu, humor bisa menjadi jalan untuk menyampaikan pesan Islam agar lebih mudah diterima di setiap kalangan masyarakat. Di tengah zaman yang sangat menghimpit humor bisa dijadikan bahan bacaan yang ringan namun syarat akan pesan kebaikan.

Dalam buku ini kemampuan Mustofa Bisri menyajikan humor dalam bentuk cerita sangat baik. Ditengah zaman yang begitu sulit, tekanan banyak datang dalam segala aspek kehidupan. Beliau menyajikan cerita humor namun bernafaskan ajaran Islam. Pesan yang disampaikan mudah untuk diterima karena disajikan dengan apik.

Di lain kesempatan, seorang wanita datang kepada Nabi Muhammad Saw. minta didoakan masuk surga.

"Belum tahukah Ibu bahwa surga tertutup bagi wanita-wanita tua?" sabda nabi menggoda.

Mendengar sabda Nabi Muhammad itu, kontan si nenek meraungraung, menanggis. Nabi pun tersenyum, katanya, "Tenang, tenang. Apa anda belum pernah membaca Firman Allah:

Kami jadikan perempuan-perempuan surga itu menjadi gadis-gadis perawan yang penuh gairah cinta dan sebaya? (QS. Al-Waqiah (56): 35-37).

Mendengar sabda Nabi itu, barulah si nenek tertawa gembira (Bisri, 2016: 2-3).

Cerita di atas merupakan salah satu humor dalam buku karya Mustofa Bisri. Dalam cerita diatas menunjukan bahwa Nabi yang dikenal dengan kegagahannya dan kearifannya ada kalanya beliau bercanda. Dalam candanya tersebut Nabi Muhammad sangat santun dan tidak ada pihak yang disakiti.

Humor yang disampaikan penulis dalam buku dari canda nabi \& sufi hingga kelucuan kita seringkali berupa sindiran maupun teguran. Banyak pelajaran yang bisa diambil dalam candaan yang ada dalam buku tersebut. Penulis menggunakan sudut pandangnya sebagai tokoh agama Islam yang sering kali dalam bukunya ini mencantumkan nama tokoh Islam.

Dari latar belakang tersebut perlu adanya penelitian lebih lanjut mengenai pesan dakwah yang disampaikan oleh A Mustofa Bisri dalam buku "Dari Canda Nabi Hingga Kelucuan Kita". Maka dilakukan penelitian dengan tiga rumusan masalah: pertama, Bagaimana Kategori pesan dakwah dalam Buku "Dari Canda Nabi dan Sufi Hingga Kelucuan Kita” Karya A. Mustofa Bisri?,kedua, Bagaimana Organisasi pesan dalam 
Buku "Dari Canda Nabi dan Sufi Hingga Kelucuan Kita" Karya A. Mustofa Bisri?, ketiga, Bagaimana Imbauan pesan dalam Buku "Dari Canda Nabi dan Sufi Hingga Kelucuan Kita" Karya A. Mustofa Bisri?.

Metode yang digunakan pada penelitian ini adalah analisis isi deskriptif dengan mengidentifikasi karakteristik kategori, organisasi, dan imbauan pesan pada buku Dari Canda Nabi \& Sufi Hingga Kelucuan Kita karya Mustofa Bisri. Dengan demikian akan menghasilkan kesimpulan tentang kategori, organisasi, dan imbauan pesan yang ada pada buku Dari Canda Nabi \& Sufi Hingga Kelucuan Kita karya Mustofa Bisri.

\section{LANDASAN TEORITIS}

Pada penelitian ini terdapat beberapa aspek yang menjadi landasan teori, diantaranya: dakwah, pesan dakwah, organisasi pesan, imbauan pesan, buku, dan humor. Landasan teori ini dimaksudkan untuk menjadi teori acuan agar penelitian bisa sesuai dengan tujuan yang penulis inginkan.

Dakwah secara etimologi berarti seruan, undangan, panggilan, atau do'a. Jika ditinjau secara istilah, dakwah ialah proses penyampaian pesanpesan kebaikan berupa ajakan, saran, undangan, untuk mengikuti pesan kebaikan guna mendorong seseorang menjadi pribadi yang lebih baik sesuai dengan ajaran agama Islam (Enjang, 2009: 4). Sedangkan, dalam prakteknya dakwah merupakan kegiatan mentranformasikan nilai-nilai agama Islam yang memiliki nilai penting dan berperan langsung dalam pembentukan persepsi umat tentang berbagai nilai kehidupan (Ilaihi, 2010: 17).

Ada beberapa unsur yang perlu diperhatikan bagi para da’i agar dakwah dapat dilaksanakan dengan sebaik-baiknya dan berjalan sesuai rencana. Pada setiap aktivitasnya dakwah melibatkan beberapa unsur, adapun unsur-unsur dakwah ialah:pertama, Subjek dakwah (da'i), kedua, objek dakwah (mad'u), ketiga, metode dakwah (uslub al-dakwah), keempat, media dakwah (wasilah al-dakwah), dan kelima, pesan dakwah (maudu aldakwah).

Pesan dakwah adalah materi ataupun pesan-pesan yang disampaikan dari seorang da'i pada para mad'u yang biasanya berisi tentang pokok ajaran Islam yang terkandung dalam Al-Qur'an ataupun hadist. Ajaran agama Islam pun meliputi berbagai aspek kehidupan, baik aspek akidah, syariah, maupun akhlak (Enjang, 2009: 80). 
Pesan dakwah adalah unsur yang sangat penting dalam keberhasilan dakwah. Seorang da'i harus bisa menempatkan pesan pada setiap mad'unya, karena setiap manusia memiliki tingkat pemahaman yang berbeda akan Islam. Da'i juga haruslah memiliki kecakapan dalam penyampaian pesan dakwah agar bisa diterima dengan baik oleh mad'u.

"Dalam retorika mengenal enam macam organisasi pesan: deduktif. Induktif, kronologis, logis, spesial, dan topikal. Pesanyangbaik akan mudah dipahami apabila tersusun dengan baik" (Rakhmat, 2012: 291).

Pesan dimaksudkan untuk memengaruhi orang lain, maka pesan tersebut harus bisa menyentuh perasaan komunikan dan mendorongnya melakukan sesuatu yang disampaikan dalam pesan tersebut. Secara psikologis pesan bisa mengimbau khalayak untuk menerima dan melaksanakan gagasan yang disampaikan komunikator. Ada lima imbauan pesan yaitu: pertama, imbauan rasional, biasanya dilakukan dengan pendekatan logis. Yakni meyakinkan orang lain dengan menunjukan bukti-bukti empiris. Kedua, imbauan emosional, berarti menggunakan pernyataan atau bahasa yang menyentuh emosi komunikan. Ketiga, imbauan takut menggunakan pesan yang mengancam, meresahkan, dan mencemaskan. Keempat, imbauan ganjaran menggunakan rujukan yang menjanjikan komunikan sesuatu yang mereka inginkan atau yang mereka perlukan. Kelima, imbauan motivasional menggunakan imbauan motif yang menyentuh kondisi intern dalam diri manusia.

Pesan dakwah seiring berjalannya waktu disampaikan dengan berbagai metode maupun media. Ditengah zaman yang sulit dan semakin menghimpit pesan dakwah dikemas dengan sedemikian rupa, salah satunya dengan sisipan humor. Humor yang disampaikan hanya sebagai sisipan bukan materi utama.

Buku adalah sekumpulan informasi atau bacaan yang disusun secara sistematis dalam satu bundel cetakan. Ditengah perkembangan zaman yang semakin pesat dengan pola penyebaran informasi begitu cepat pada media online, namun buku tetap menjadi salah satu media penting dalam penyebaran informasi pada setiap manusia.

Humor berasal dari bahasa Latin yaitu umor yang berarti cairan. Konotasi cairan merujuk pada suasana hati yang mencairditandai tawa dan perasaan senang, riang, dan gembira (Ridwan, 2013: 2).

Dalam Ensiklopedia Indonesia, humor didefinisikan sebagai kualitas untuk menghimbau rasa geli atau lucu, karena keganjilannya atau ketidakpantasannya yang menggelikan; paduan antara rasa kelucuan 
yang halus di dalam diri manusia dan kesadaran hidup yang iba dengan sikap simpatik (Ridwan, 2010: 926).

Humor dapat menjadi sarana menyampaikan siratan sindiran, atau suatu kritikan yang bernuansa tawa. Humor juga dapat menjadi sebuah komunikasi yang bersifat persuasif, untuk mempermudah masuknya informasi atau pesan yang ingin disampaikan sebagai sesuatu yang serius dan formal.

Berdasarkan uraian diatas dapat ditarik kesimpulan bahwa humor adalah sebagai suatu komunikasi jenaka yang menggelikan hati, menimbulkan kelucuan dan dapat memancing gelak tawa baik disebabkan karena unsur superioritas, ketidakseimbangan, atau pembebasan ketegangan atau tekanan yang memiliki efek tertawa yang akhirnya akan menimbulkan suasana hati yang senang, riang, dan gembira.

Humor bukanlah aktivitas komunikasi biasa yang hanya membuat hati senang dan menimbulkan tawa, namun humor secara keilmuan mempunyai fungsi yang sama dengan pesan-pesan dakwah, fungsi dakwah yakni: pertama, melaksanakan segala keinginan dan segala tujuan gagasan atau pesan, kedua, humor dapat menyadarkan orang bahwa dirinya tidak selalu benar, ketiga, humor dapat mengajar orang melihat persoalan dari berbagai sudut, keempat, humor dapat menghibur, kelima, humor dapat melancarkan pikiran, keenam, humor dapat membuat orang mentolerir sesuatu, ketujuh, humor dapat membuat orang memahami soal pelik (Rahmanadji, 2007: 218). Dilihat dari fungsinya, terlihat bahwa humor bisa dijadikan sebagai pesan dakwah, tanpa disadari di saat kita sedang tertawa, pesan-pesan dakwah dapat dengan mudah masuk ke dalam memori kita.

Pesan dakwah berisikan tentang ajaran agama islam secara universal yang terkandung dalam Al-qur'an dan hadist, tidak harus selalu ada kata dakwah. Selama pesan yang disampaikan masih mengandung ajakan pada kebenaran, meningkatkan keimanan dan ketakwaan kepada Allah, menampakan keadilan, kemaslahatan, dalam kehidupan sehari maka itu termasuk pesan dakwah. Begitupula dengan humor sebagai pesan dakwah, walaupun mempunyai sifat untuk menghibur tetapi, jika didalamnya mengandung ajakan untuk beriman dan taqwa kepada Allah, mengajak orang lain menuju jalan kebaikan maka hal tersebut bisa dikatakan sebagai proses penyampaian pesan dakwah.

Namun humor hanyalah sisipan dalam kegiatan dakwah yang tidak 
boleh melebihi porsinya karena dikhawatirkan akan menggeser hakikat dakwah sebagai kegiatan normatif menjadi semacam dagelan dan guyonan belaka. Perubahan hakikat tuntunan menjadi tontonan sebagaimana dikhawatirkan banyak pihak nampaknya akan terjadi bila humor tidak diposisikan sebagai sisipan belaka (Ridwan, 2013: 37).

\section{HASIL DAN PEMBAHASAN}

Buku hasil karya Mustofa Bisri ini pada awalnya adalah cerita-cerita pada acara televisi. Cerita lucu yang diharapkan bisa menjadi semacam obat yang mengobati (walau sementara) pening kawan-kawan. Namun karena sambutan yang baik dari masyarakat maka pada akhirnya cerita-cerita tersebut dibukukan.

Dalam buku ini terdapat begitu banyak pesan-pesan dakwah, tetapi hanya beberapa pesan saja yang akan dicantumkan. Ada banyak cerita baik itu dari rasululah SAW, para sahabat, ataupun para sufi yang bisa menjadi jalan untuk lebih memperbaiki diri. Buku "Dari Canda Nabi \& Sufi Sampai Kelucuan Kita" tidaklah terlalu tebal kurang lebih hanya 150 halaman. Dalam buku tersebut terdapat 20 bab, dan disetiap bab ada beberapa cerita yang didalamnya mengandung pesan.

Analisis isi buku "Dari Canda Nabi \& Sufi Sampai Kelucuan Kita" bertujuan untuk mengidentifikasi kategori pesan dakwah, organisasi pesan, dan imbauan pesan. Kategori pesan dakwah dibagi menjadi tiga yakni: akidah, syariah, dan akhlak. Organisasi pesan yang terdiri dari enam pola yakni pola deduktif, induktif, topikal, spasial, kronologis, dan logis. Sementara imbauan pesan terdiri dari lima imbauan yakni: imbauan emosional, rasional, takut, motivasional, dan ganjaran.

Berdasarkan analisis data diperoleh 18 data yang bersangkutan dengan tiga kategori pesan dakwah, yaitu kategori akidah yang berkaitan dengan ditemukan 11 pesan, kategori syariah ditemukan 5 pesan, dan kategori akhlak ditemukan 2 pesan. Pada organisasi pesan ditemukan 23 data yang bersangkutan dengan enam pola organisasi pesan yaitu, organisasi pesan dengan pola deduktif 2 pola, organisasi pesan dengan pola induktif 3 pola, organisasi pesan dengan pola kronologis 7 pola, organisasi pesan dengan pola logis 3 pesan, organisasi pesan dengan pola spasial 4 pesan, dan organisasi pesan dengan pola topikal 4 pesan. Pada imbauan pesan ditemukan 11 data yang bersangkutan dengan lima imbauan pesan yaitu, imbuan rasional 5 imbauan, imbauan emosional 5 
imbauan, dan imbauan motivasional 1 imbauan.

\section{Kategori Pesan Dakwah}

Kategori pesan dakwah akidah dengan sub kategori iman kepada Allah terdapat pada tema-tema berikut:

"Suatu hari Zahir sedang berada di salah satu pasar Madinah, ketika diam-diam Rasulullah Saw. mendatanginya dari belakang dan memeluknya kuat-kuat seraya bersabda, "Siapa yang mau membeli budak saya ini?" Zahir kaget dan menoleh, ternyata Rasulullah Saw. buru-buru Zahir pun mencium tangan beliau dan berkata, "Lihatlah, ya Rasullah, saya tidak laku dijual." "Tidak, Zahir," sahut Nabi, "di sisi Allah hargamu sangat tinggi" (Bisri, 2016: 2).

Dari dialog "di sisi Allah hargamu sangat tinggi", Rasulullah menerangkan pada kita semua bahwa segala sesuatu pasti ada ganjaran dari Allah SWT. Allah tidak melihat manusia dari paras maupun harta melainkan pada keimanannya. Meskipun di mata manusia Zahir adalah seorang budak namun bisa jadi di mata Allah Zahir lebih mulia. Rasulullah bersabda:

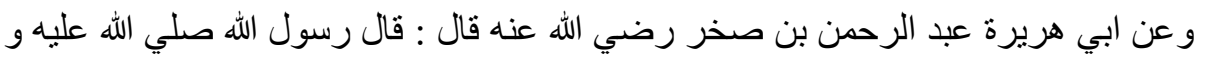
سلم : ان الله لا ينظر الي اجسامكم و لا الي صوركم ، ولرئ ولكن ينظر الي قلوبكم

Diriwayatkan dari Abu Hurairah Abdirrahmanbin syahrin radhiyallahu 'anhu, Rasulullah Salallahu 'Alaihi Wa sallam bersabda, "Sesungguhnya Allah tidak melihat kepada tubuh kalian dan tidak pula kepada rupa kalian, tetapi Dia melihat kepada hati kalian."

Kewajiban kita sebagai seorang hamba adalah beriman dan beribadah kepada Allah. Ketampanan, kecantikan, dan kekayaan tidak menjamin apa-apa. Semua itu tidak harganya di sisi Allah. Maka sepatutnya kita selalu meningkatkan keimanan dan ketaqwaan, sebagaimana tugas dari manusia ialah beribadah kepada Allah. Karena sesungguhnya manusia yang paling mulia di sisi Allah ialah yang paling bertakwa. Allah berfirman dalam surat Al-Hujurat ayat 13:

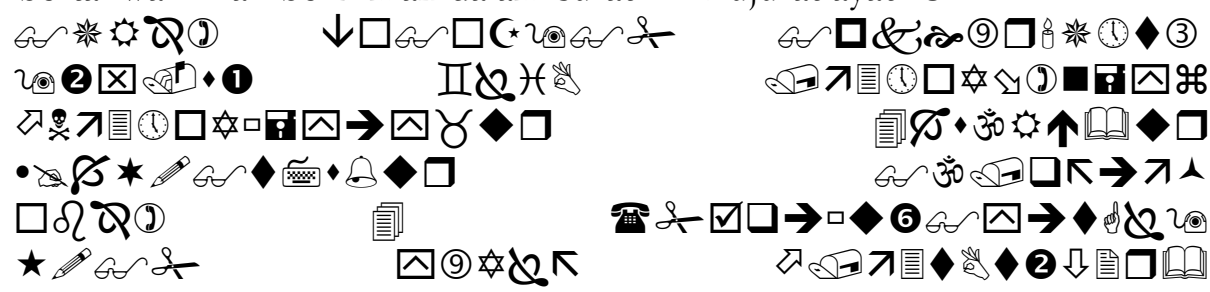




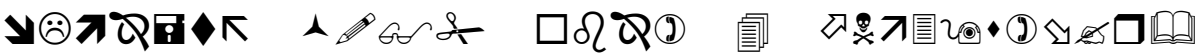

$<32$ Q

Wabai manusia! Sungguh Kami telah menciptakan kamu dari seorang lakilaki dan seorang perempuan dan menjadikan kamu berbangsa - bangsa dan bersuku-suku agar kamu saling kenal-mengenal. Sungguh, yang paling mulia diantara kamu disisi Allah ialah orang yang paling taqwa diantara kamu. Sungguh Allah Maha mengetabui lagi Maha Teliti (Departemen Agama RI, 2004: 517).

"Ketika semua keinginan yang terpikirkan sudah disampaikan dan tidak mampu lagi mengajukan keinginan yang lain, Allah pun membantunya dengan mengatakan, "Kau tidak ingin ini; tidak ingin itu?" semua yang diingatkan Tuhannya pun dia iyakan. Sampai ketika semua harapan dan keinginan tuntas, Allah pun berfirman, "Itu semua untukmu ditambah semisal itu!" Allahu Akbar! Betapa liciknya manusia dan betapa agungnya kemurahan Allah terhadap hamba-Nya yang bernama manusia itu! (Bisri, 2016: 7).

Kalimat "Allahu Akbar! Betapa liciknya manusia dan betapa agungnya kemurahan Allah terhadap hamba-Nya yang bernama manusia itu!" mengingatkan pada kita akan keagungan Allah. Pada awal cerita ada seorang manusia yang berdiri diantara surga dan neraka. Wajahnya menghadap neraka. Orang tersebut mengiba memohon kepada Allah untuk dipalingkan wajahnya dari api neraka ke pintu surga. Setelah permintaan tersebut dikabulkan manusia itu melihat betapa indahnya pintu surga ia mengiba kembali lalu Allah mengabulkan maka begitulah seterusnya hingga semua yang diinginkan terpenuhi.

Allah Maha Agung dengan segala kebaikannya mengabulkan permintaan manusia namun terkadang manusia tidak tahu diri dan kurang bersyukur akan karunia Allah. Janji Allah bagi hamba-Nya yang senantiasa bersyukur atas nikmat yang telah Allah berikan tersurat dalam Al-qur'an Surat Ibrahim ayat 7:

Dan (ingatlah), ketika Tuhan-mu memaklumkan, "Sesungguhnya jika kamu bersyukur, niscaya aku akan menambah (nikmat) kepadamu, tetapi jika kamu mengingkari (nikmat-Ku), Maka pasti azab-Ku sangat pedih" (Departemen Agama RI, 2004: 256).

"Sahabat Abdullah bin Umar, purta sahabat Umar bin Khattab, pernah menggoda tetangganya dan mengatakan, "Aku diciptakan oleh Pencipta manusia-manusia yang mulia; sedangkan kau 
diciptakan oleh Pencipta manusia-manusia yang jahat” (Bisri, 2016: 12).

Dialog Abdullah bin Umar, "Aku diciptakan oleh Pencipta manusia-manusia yang mulia; sedangkan kau diciptakan oleh Pencipta manusia-manusia yang jahat." Ketika beliau menggoda tetangganya. Namun karena perkataan tersebut tetangga pun marah, berteriak-teriak, dan menanggis. Sementara Abdullah bin Umar sendiri tertawa geli.

Si tetangga sebenarnya tidak perlu marah, jika dicermati candaan tersebut memang benar adanya. Orang-orang mulia maupun orang-orang jahat diciptakan oleh Tuhan yang sama. Allah yang telah menciptakan segala sesuatu di muka bumi bahkan jagat raya. Pesan keimanan bahwa Allah yang menciptakan semua.

Allah berfirman dalam surat surat Ar-Ra'd ayat 16:

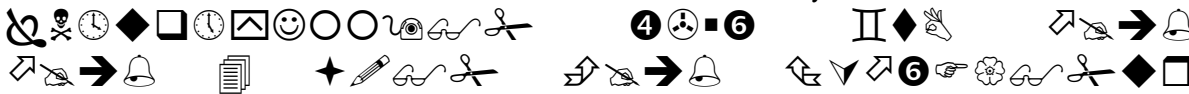

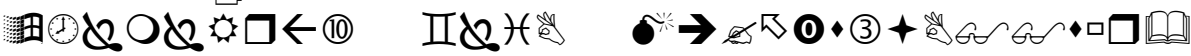

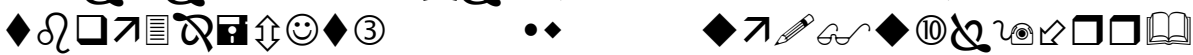

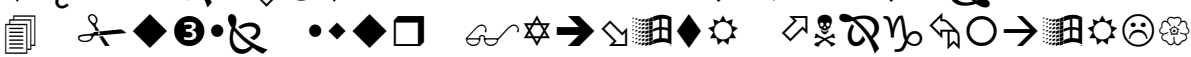

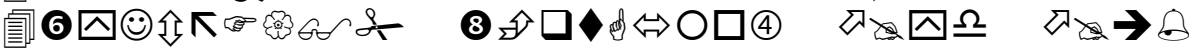

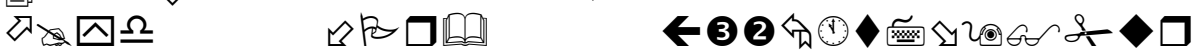

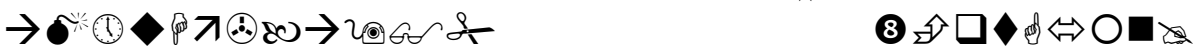

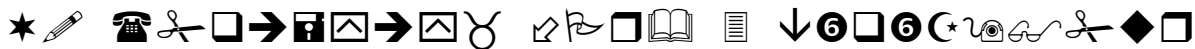

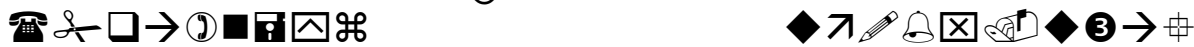
- $0<8$ (1) $\rightarrow$

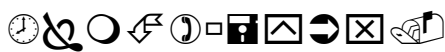

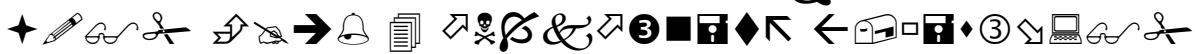

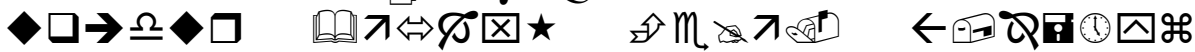

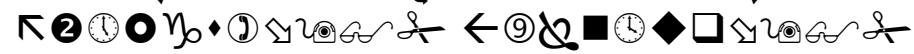
"Katakanlab (Mubammad): "Siapakah Tuban langit dan bumi?" Katakanlah: "Allab". Katakanlah: "Pantaskah kamu mengambil pelindungpelindung selain Allah, Padahal mereka tidak kuasa mendatangkan manfaat maupunmenolak mudharat bagi dirinya sendiri?". Katakanlah: "samakah orang buta dan yang dapat melihat, atau samakah gelap gulita dan terang benderang; Apakah mereka menjadikan beberapa sekutu bagi Allah yang dapat menciptakan seperti ciptaan-Nya sebingga kedua ciptaan itu serupa menurut pandangan mereka?" Katakanlah: "Allah adalab Pencipta segala sesuatu dan Dia Tuban yang Maha Esa, Maha Perkasa" (Departemen Agama RI, 2004: 251). 
Kategori pesan dakwah dengan sub kategori iman kepada qadha dan qodhar dapat dilihat dari kutipan berikut:

"Orang-orang bertanya pada Joha, "Mana yang lebih bermanfaat, matahari atau bulan?"

Tanpa berpikir panjang, Joha menjawab dengan tegas, "tentu saja bulan hauh lebih bermanfaat ketimbang matahari!"

"Mengapa?"

"Sebab matahari muncul di siang hari pada saat manusia tidak membutuhkannya, sementara bulan muncul di gelap malam pada saat manusia sangat membutuhkannya" (Bisri, 2016: 46).

Dalam kalimat "Sebab matahari muncul di siang hari pada saat manusia tidak membutuhkannya, sementara bulan muncul di gelap malam pada saat manusia sangat membutuhkannya." mengandung pesan iman kepada qadha dan qadr uang telah Allah tentukan. Candaan Joha bahwa matahari muncul di siang hari pada saat manusia tidak membutuhkannya sedangkan bulan yang muncul di malam gelap gulita saat manusia sangat membutuhkannya, menunjukan bahwa Joha meyakini akan ketetapan Allah akan pergantian siang dan dan malam.

Hakikatnya matahari maupun bulan sangatlah bermanfaat dalam kehidupan manusia karena Allah telah mengatur dengan sebaik-baiknya. Sesungguhnya dari semua itu merupakan tanda-tanda kekuasaan Allah bagi orang-orang yang berpikir. Sebagaimana Allah telah menjelaskan dalam surat Ali-Imran 190:

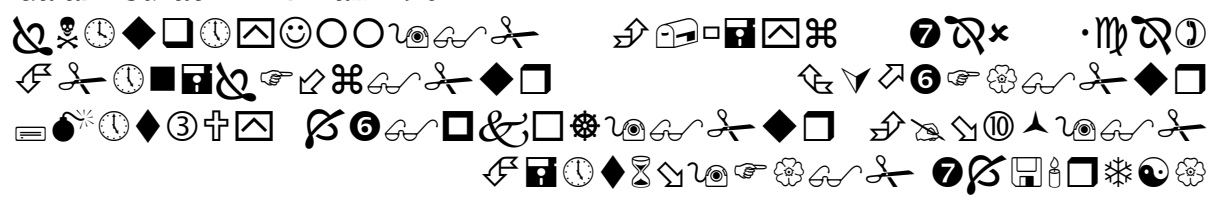

Sesunggubnya dalam penciptaan langit dan bumi, dan silib bergantinya malam dan siang terdapat tanda-tanda bagi orang-orang yang berakal (Departemen Agama RI, 2004: 75).

Adapun paragraf atau dialog dalam buku yang mengandung pesan ibadah dapat dilihat dari kutipan sebagai berikut:

"Seperti diketahui, menurut hukum Islam, orang yang berpuasa dilarang besetubuh di siang hari. Barang siapa melanggar larangan ini, di samping puasa yang bersangkutan batal, ia dikenakan sanksi (kaffarat) memerdekakan budak. Apabila tidak menemukan budak, wajib berpuasa dua bulan berturut-turut, tanpa terputus. Bila tidak mampu diharuskan memberi makan 60 orang miskin” (Bisri, 2016: 
3).

Dalam paragraf diatas menjelaskan bahwa ada beberapa larangan dalam melaksanakannya. Larangan tersebut salah satunya adalah bersetubuh bagi suami istri, jika melakukannya maka akan dikenakan sanksi yang berat. Sanksi tersebut adalah memerdekakan budak, namun di zaman sekarang sudah sangat sulit ditemukan budak maka bisa diganti dengan berpuasa dua bulan berturut-turut. Bila tidak mampu juga maka harus memberi makan pada 60 orang miskin.

Puasa menurut agama Islam ialah menahan diri dari sesuatu yang membatalkannya, selama satu hari, muali dari terbit fajar sampai terbenamnya matahari dengan niat dan beberapa syarat. (Rasyid, 2011:220)

Ada beberapa perkara yang membatalkan puasa, salah satunya dalah bersetubuh di siang hari. Namun bersetubuh di malam hari itu dihalalkan, sebagaimana firman Allah dalam surat Al-Baqarah ayat 187:

Dihalalkan bagi kamu pada malam hari bulan puasa bercampur dengan isteri-isteri kamu; mereka adalah pakaian bagimu, dan kamupun adalah pakaian bagi mereka. Allah mengetahui bahwasanya kamu tidak dapat menahan nafsumu, karena itu Allah mengampuni kamu dan memberi ma'af kepadamu. Maka sekarang campurilah mereka dan ikutilah apa yang telah ditetapkan Allah untukmu, dan Makan minumlah hingga terang bagimu benang putih dari benang hitam, Yaitu fajar, kemudian sempurnakanlah puasa itu sampai (datang) malam, (tetapi) janganlah kamu campuri mereka itu, sedang kamu beri'tikaf dalam mesjid. Itulah larangan Allah, Maka janganlah kamu mendekatinya. Demikianlah Allah menerangkan ayat-ayat-Nya kepada manusia, supaya mereka bertakwa (Departemen Agama RI, 2004: 29).

Dalam kehidupan bermasyarakat manusia haruslah selalu menjaga hubungan baik dengan sesama. Salah satu cara yang dianjurkan dalam Islam adalah menjawab salam. Salam yang biasa kita ucapkan sehari-hari bila diartikan dalam bahasa indonesia adalah keselamatan bagimu. Dengan mengucapkan salam kita mendoakan orang lain begitu pun yang menjawab salam mendoakan orang yang memberinya salam.

Allah berfirman dalam Al-Quran Surat Al-Nuur ayat 27: "Wahai orang-orang yang beriman! Janganlah kamu memasuki rumah yang bukan rumahmu sebelum meminta izin dan memberi salam kepada penghuninya. 
Yang demikian itu lebih baik bagimu, agar kamu (selalu) ingat" (Departemen Agama RI, 2004: 352).

Dari ayat diatas sangat jelas kita ketahui akan anjuran mengucapkan salam. Ketika kita hendak bertamu maka haruslah mengucapkan salam terlebih dahulu dan kita tidak diperbolehkan masuk sebelum mendapat izin dari pemilik rumah.

Manusia merupakan makhluk sosial yang membutuhkan orang lain dalam kehidupannya. Sebagai seorang muslim harus memili akhlak yang mulia karena sesungguhnya Rasulullah diutuh untuk menyempurnakan akhlak manusia. Menjaga hubungan baik dengan manusia adalah sebuah keharusan.

"Ada seorang dari kabilah Asyja' bernama Zahir bin Haram yang sering sowan kepada Nabi Muhammad Saw. dan selalu membawa hadiah dari dusun untuk pemimpinnya yang dicintai itu" (Bisri, 2016: 1).

"Suatu hari, Nu'aiman menghadiahi nabi Muhammad Saw. seguci madu. Nu'aiman menyuruh penjual madu untuk mengantarkan seguci madu itu kepada Nabi dan berkata, "nanti kamu minta juga uang harganya" mendapat hadiah madu dan dan tagihan harganya, Nabi pun bersabda, "ini pasti ulah Nu'aiman lagi!" Nu'aiman pun dipanggil dan ditanya, "kenapa kau lakukan hal ini?” Dengan kalem Nu'aiman pun menjawab, "saya ingin berbuat baik kepada Anda Ya Rasulullah, tapi saya tidak punya apa-apa." Nabi pun tersenyum dan memberikan uang madu kepada si penjualnya (Bisri, 2016: 9).

Dalam dua teks cerita diatas menceritakan tentang pemberian hadiah kepada Rasulullah. Ada anjuran Rasulullah untuk saling memberi hadiah. Tidak memberi hadiah dikarenakan perayaan tertentu yang merupakan budaya non-Islam seperti ulang tahun, hari valentine, dan lain sebagainya.

Dari penelitian yang dilakukan dapat dilihat beberapa judul-judul cerita yang sejalan dengan kategori pesan dakwah, baik kategori akidah, syariah, maupun akhlak. Buku ini banyak menyampaikan pesan dakwah dengan kategori akidah dengan berbagai sub kategori.

Pokok-pokok ajaran agama Islam yang juga merupakan pesan dakwah terdapat tiga kategori, yaitu: Pertama, akidah, yang meliputi iman kepada Allah SWT, iman kepada malaikat-malaikat Allah, iman kepada kitab-kitab Allah, iman kepada Rasul-Rasul Allah, iman kepada hari kiamat, dan iman kepada qadla dan qadar. Kedua, syariah, yang meliputi 
ibadah dalam arti khas (thaharah, shalat, puasa, zakat, haji) dan muamalah dalam arti luas (hukum perdata dan hukum publik). Ketiga, Akhlak, yang meliputi akhlak kepada al-khaliq dan makhluq (Aziz, 2009: 325).

\section{Organisasi pesan}

Tulisan bisa diklasifikasikan dalam beberapa bentuk organisasi pesan. Organisasi pesan berarti cara menyusun pesan mengikuti pola-pola yang disarankan oleh aristoteles, yaitu deduktif, induktif, kronologis, logis, spasial, dan topikal.

Dibawah ini dikutip sebagian isi dari beberapa tulisan dalam tema cerita dalam buku Dari Canda Nabi \& Sufi Hingga Kelucuan Kita berdasarkan organisasi pesan.

"Menjenguk orang sakit termasuk dianjurkan oleh agama. Sebagaimana ajaran yang lain, menjenguk orang sakit pun ada etikanya yang apabila tidak diikuti bisa berakibat buruk atau lucu" (Bisri, 2016: 64).

Kutipan diatas termasuk kedalam pola deduktif dengan gagasan utama di awal paragraf yakni berbicara akan anjuran menjenguk orang sakit lalu dilanjutkan dengan adanya etika dalam anjuran tersebut.

Pola induktif mengemukakan perincian kemudian kesimpulan. Dan contoh pola deduktif pada tema "Ulama Suu."

Pernah belajar agama sebentar atau dengar dari sana, beberapa ayat dan dari sini, sedikit hadis, lalu memploklamir-kan diri sebagai orang alim, syeikh atau kiai. Untuk mendukung hal ini, tinggal mengatur cara berpakaian dan caranya. Agar tampak gagah dan berwibawa, bersorban mesti besar, tasbih selalu di tangan, dan lebih afdol lagi bila memelihara jenggot. Ciri orang yang begini, suka over acting. Umumnya mereka sangat gemar bergaul dengan kalangan penguasa, gampang memberi nasihat atau fatwa, dan fatwa-nya biasanya ngawur. Mereka inilah yang oleh sementara ulama beneran disebut ulama dunia atau ulama suu' (Bisri, 2016: 27).

Berdasarkan paragraf diatas pembaca akan menetahui ciri-ciri dari ulama suu'. Penulis menerangkan sedikit demi sedikit ciri dari ulama dunia atau ulama suu' yang hanya banyak berlagak. Pada kalimat terakhir disimpulkan bahwa seorang yang kapasitas keilmuannya masih sedikit dan berlagak seperti seorang olama bisa disebut dengan ulama dunia atau ulama suu'. 
Pola kronologis yaitu pesan yang disusun berdasarkan urutan waktu terjadinya peristiwa. Pola kronologis dimulai dengan pemaparan terjadinya suatu peristiwa yang bisa meyakinkan pembaca untuk memahami secara mendalam pesan yang ada dalam tema yang disajikan. Contoh pola tersebut pada tema cerita "Seniman dan Perempuan".

Abu Aina' melamar seorang perempuan dan ditolak karena wajahnya buruk. Maka dia pun mengirimkan puisi kepada perempuan itu yang intinya mengatakan bahwa meskipun dia buruk rupa tapi dia adalah sastrawan besar yang terkenal.

Menerima surat Abu Aina' yang berisi puisi itu, si perempuan pun membalasnya singkat, "Aku tidak membutuhkanmu untuk menjadi pengurus dewan kesenian” (Bisri, 2016: 58).

Pada kutipan diatas menceritakan bahwa seorang lelaki ingin mempersunting seorang wabita yang cantik sementara ia buruk rupa. Lelaki itu langsung mengirimkan surat yang berisi puisi dengan maksud agar perempuan itu mau padanya. Setelah menerima surat perempuan pun membalas suratnya yang intinya ia menolak sang laki-laki.

Dalam pola logis pesan disusun berdasarkan sebab-akibat atau akibat-sebab dalam pola penulisannya. Dengan penalaran logis yang dimulai dengan sebab-akibat atau akibat-sebab pembaca akan lebih mudah memahami pesan yang ada didalamnya. Pola tersebut dapat dilihat pada tema cerita "Berkhutbah di dalam sumur"

Mendengar itu, Ubad, salah seorang yang ikut mendengarkan komentar, "Anda yang akan kesulitan, Amirul Mukminin; seandainya dulu sahabat Utsman berbuat seperti para pendahulunya, kemudian menjadi tradisi, bila seorang khalifah berkhotbah berdiri di tangga setingkat di bawah pendahulunya, niscaya Anda akan berdiri berkhotbah di dalam sumur" (Bisri, 2016: 14).

Kutipan diatas menjelaskan tentang sebab dan akibat Khalifah Utsman saat berkhutbah tidaklah turun satu tingkat di mimbar seperti halnya yang dilakukan Abu Bakr, malah Utsman berdiri di tempat Rasulullah saat khutbah. Bila kebiasaan itu sampai sekarang terus menjadi tradisi dengan turun satu tingkat maka akibatnya saat ini khutbah bisa di dalam sumur. Untung saja Utsman tidak mengikuti Khalifah sebelumnya.

Pola spasial itu berdasarkan tempat. Pola tersebut dapat dilihat pada tema cerita "Mas kawin yanng tidak sebanding"

Suatu hari Umar bin Khattab r.a. memperhatikan seseorang yang 
bersembahyang di masjid. Orang itu bersembahyang dengan cepat dan tergesa-gesa, kemudian berdoa, "Ya Allah, kawinkanlah aku dengan bidadari-Mu" Umar pun berkata kepada orang tersebut, "Hei, bung, maskawinmu terlalu kecil untuk lamaranmu yang begitu besar !" (Bisri, 2016: 8).

Dalam tema Mas kawin yang tidak sebanding menguraikan tentang seorang yang sedang di masjid. Dalam masjid tersebut ia sembahyang dan berdoa meminta pada Allah agar dinikahkan dengan dengan bidadari-Nya.

Pola topikal yaitu pola pesan yang diletakan sesuai topik pembicaraan, mulai dari pembicaraan yang penting ke kurang penting, atau mudah ke sukar. Salah satu contoh pola topikal pada tema cerita "Kaki yang kiri tidak berwudhu".

Suatu hari Joha berwudhu dan ternyata air yang dipergunakan untuk wudhu kurang, sehingga kaki kirinya tidak kebagian air dan tidak dibasuh. Maka Joha pun bersembahyang dengan mengangkat kaki kirinya.

Ketika kemudian orang-orang bertanya, dia menjawab, "Kakiku yang kiri tidak berwudhu!" (Bisri, 2016: 40).

Kutipan diatas menunjukan satu topik yakni tentang wudhu. Dimulai dari saat awal berwudhu hingga abis air dan tidak bisa melanjutkan wudhunya. Diawali dengan yang penting lalu ke yang kurang penting.

Dari hasil analisis organisasi pesan pada buku Dari Canda Nabi \& Sufi Sampai Kelucuan Kita terdapat enam jenis organisasi pesan yaitu: Deduktif, Induktif, Kronologis, Logis, Spasial, dan Topikal. Pada tiap bentuk organisasi pesan yang disampaikan oleh pengarang terdapat maksud dan tujuan yang ingin disampaikan pada pembaca.

Pola deduktif ada pada dua tema cerita, yaitu: Seandainya orang tolol mau diam dan tertawa bersama orang sakit. Pada kedua tema cerita ini pengarang membawa kita pada gagasan utama di awal paragraf lalu memberikan penjelasan pada kalimat selanjutnya. Pada tema "Seandainya orang tolol mau diam" gagasan utamanya adalah diam dan bicara ada pada tempatnya masing-masing, lalu dilanjutkan dengan penjelasan akan akibat dari banyak bicara namun malah bisa menimbulkan masalah. Tema cerita selanjutnya pun tak jauh berbeda, anjuran agar menjenguk orang sakit lalu dilanjutkan dengan etika saat menjenguk orang sakit.

Pola Induktif terdapat pada tiga tema cerita, yaitu: Orang Terakhir 
Yang Masuk Surga, Dimana Sebaiknya Berjalan, Ulama Suu'. Tiga cerita ini memaparkan perincian-perincian lalu dibuat kesimpulan. Pada tema cerita Ulama Suu' di awal paragraf menjelaskan ciri-ciri dari orang yang mengaku ulama namun masih sangat sedikit ilmunya. Dari perincian tersebut kemudian pengarang memberikan kesimpulan bahwa orang seperti itu dinamakan Ulama Suu'.

Pola kronologis banyak digunakan pada buku ini. Ada enam tema dengan pola kronologis, yaitu: Canda sang pemimpin, Di surga tak ada perempuan tua, Keluarga paling miskin, Nu'aiman dan orang buta, Buta mata dan buta hati, Seniman dan perempuan, Menunggu doa dikabulkan. Pola kronologis menitik beratkan pada urutan waktu dari kejadian pada cerita. Pola ini membawa pembaca pada setiap kejadian dari waktu ke waktu.

Pola logis terdapat pada tiga tema cerita, yaitu: Berkhutbah di dalam sumur, dia berdua masuk surga, mukjizat sang pengaku nabi. Pengarang menggunakan pola logis untuk menjelaskan sebab dan akibat dari suatu hal.

Pola spasial terdapat pada empat tema cerita, yaitu: Maskawin yang tidak sebanding, walikota menunda jumatan, saya juga rajin berpuasa, kau saja Mad.

Pola topikal terdapat pada empat tema cerita, yaitu: Nu'aiman menghadiahi nabi, kaki yang kiri tidak berwudhu, si tamak dan si kikir, khutbah gaya tabligh.

Organisasi pesan adalah rangkaian penyusunan pesan agar memudahkan pengertian, pengingatan dan tindakan. Penyajian pesan yang tersusun dengan baik akan lebih efektif dibandingkan pesan yang tidak tersusun. Retorika menunjukan cara menyusun pesan mengikuti cara yang dikemukakan Aristoteles. Ada enam macam organisasi pesan: induktif, deduktif, logis, kronologis, logis, topikal, dan spasial (Rakhmat, 2012: 291).

\section{Imbuan Pesan}

Imbauan pesan yang jelas akan membuat komunikasi yang efektif. Adapun imbauan itu bisa berupa imbaun rasional, imbauan emosional, imbauan takut, imbauan ganjaran, dan imbauan motivasional. Adapun tema yang termasuk dalam imbauan pesan sebagai berikut:

Imbauan rasional ialah dengan meyakinkan orang lain dengan pendekatan logis dan penyajian akan bukti-bukti. Adapun Imbauan 
rasional pada buku "Dari Canda Nabi \& Sufi Sampai Kelucuan Kita" ada dalam tema "Zodiak Adam dan Iblis"

Mendengar pertanyaan yang aneh ini, orang-orang yang berada di majelis Syaikh Mawardi sendiri dengan sabar menjawab, "Kawan, seperti kau ketahui, bintang seseorang diketahui hari lahirnya. Karena itu, sebaiknya kau cari tahu lebih dahulu hari lahir bapak Adam dan Iblis; setelah itu kau boleh kembali kemari, nanti aku terangkan bintang mereka" (Bisri, 2016: 15).

Dalam kutipan diatas mengungkapkan bahwa rasi bintang itu hanya hal yang masih dugaan belaka. Selayaknya tidak perlu dipercayai. Nabi Adam juga belum diketahui zodiaknya.

Imbauan emosional menggunakan pernyataan-pernyataan atau bahasa yang menyentuh komunikan. Biasanya manusia jika sudah tersentuh hatinya maka akan mudah dalam melakukan. Imbauan emosional ada dalam tema cerita "penghuninya tak banyak omong"

Seorang wali nyentrik dari Baghdad bernama Bahlul, oleh banyak orang, boleh dianggap tolol bahkan gendheng. Dia suka dan hampir setiap hari bermain-main dikuburan. Banyak yang geli menertawakan perilakunya ini. Ketika diantara mereka ada yang bertanya tentang kegemarannya itu, si Bahlul pun menjawab, "Aku suka di kuburan karena penghuni-penghuninya tak banyak omong. Tidak suka menggunjing orang. Tidak suka berkelahi dengan sesama dan selalu mengingatkan aku akan kesementaraan dan kefanaan kehidupan ini”" (Bisri, 2016: 19).

Dengan kutipan diatas penulis ingin menghimbau akan kesementaraan hidup didunia. Kematian adalah hal yang mutlak. Sering kali orang di dunia ini hanya saling menggunjing satu sama lain, bahkan berkelahi. Akhirat adalah tempat yang kekal.

Imbauan motivasional menggunakan imbauan motif yang menyentuh kondisi intern dalam diri manusia. Adapun imbauan motivasional dapat dilihat dalam tema cerita "Mas kawinmu tidak sebanding."

Suatu hari Umar bin Khattab r.a. memperhatikan seseorang yang bersembahyang di masjid. Orang itu bersembahyang dengan cepat dan tergesa-gesa, kemudian berdoa, "Ya Allah, kawinkanlah aku dengan bidadari-Mu” Umar pun berkata kepada orang tersebut, "Hei, bung, maskawinmu terlalu kecil untuk lamaranmu yang begitu 
besar !" (Bisri, 2016: 8).

Dari kutipan diatas penulis memberikan pola motivasional agar pembaca bisa lebih giat dalam berusaha. Tugas manusia adalah untuk berusaha dengan sebaik-baiknya lalu berdoa agar selalu diberikan kemudahan.

Dalam buku ini di temukan tiga jenis imbauan pesan, yaitu: imbauan rasional, imbauan emosional, dan imbauan motivasional. Sedangkan imbauan takut dan imbauan ganjaran tidak ditemukan dalam buku ini.

Imbauan rasional terdapat pada lima tema cerita, yaitu: Berkhutbah di dalam sumur, zodiak Adam dan Iblis, seandainya orang tolol mau diam, mukjizat sang pengaku nabi, menunggu doa dikabulkan.

Imbauan emosional terdapat pada lima tema cerita, yaitu: Canda sang pemimpin, di surga tak ada perempuan tua, penghuninya tak banyak omong, dia berdua masuk surga, berpikir sebelum bertindak.

Imbauan motivasional terdapat pada satu tema cerita, yaitu tema mas kawin tak sebanding.

Imbauan pesan ialah mengimbau khayalak untuk menerima dan melaksanakan gagasan yang disampaikan komunikator. Ada lima jenis imbauan, yaitu: imbauan rasional, imbauan emosional, imbuan takut, imbuan ganjaran, dan imbauan motivasional (Rakhmat, 2012: 294).

\section{PENUTUP}

Mengacu pada rumusan masalah dan tujuan penelitian buku "Dari Canda Nabi \& Sufi Sampai Kelucuan Kita" dapat diambil kesimpulan sebagai berikut:

Kategori pesan dakwah pada buku "Dari Canda Nabi \& Sufi Sampai Kelucuan Kita" terdapat tiga jenis pesan yaitu kategori pesan Akidah, kategori pesan Syariah, dan kategori pesan Akhlak. Pesan Akidah dalam buku "Dari Canda Nabi \& Sufi Sampai Kelucuan Kita" lebih dominan dari pesan Syariah dan akhlak.

Organisasi pesan pada buku "Dari Canda Nabi dan Sufi Sampai Kelucuan Kita" memiliki beberapa bentuk yang bervariasi dan berubahubah pada setiap tema nya. Ada pola pesan deduktif, induktif, kronologis, logis, spasial, dan topikal. Variasi dimaksudkan agar tidak monoton pada setiap tema ceritanya. Dari hasil penelitian organisasi pesan yang dominan dalam buku "Canda Nabi \& Sufi Sampai Kelucuan Kita" diketahui 
organisasi pesan kronologis lebih dominan dibanding organisasi pesan lainnya. Tema cerita banyak yang berdasarkan pada pola organisasi kronologis dengan urutan kejadian yang saling berkesinambungan dari waktu ke waktu.

Imbauan pesan pada buku "Dari Canda Nabi \& Sufi Sampai Kelucuan Kita" ada tiga yaitu: imbauan pesan rasional, imbauan pesan emosional, dan imbauan pesan motivasional. Tak satu pun dalam tema cerita yang terdapat imbauan pesan takut dan imbauan pesan ganjaran. Sementara itu, pada buku "Dari Canda Nabi \& Sufi Sampai Kelucuan Kita" imbauan pesan yang paling dominan adalah imbauan pesan rasional dan imbauan emosional dibandingkan dengan imbauan pesan lainnya. Penulis lebih memilih untuk banyak menghimbau pembaca dengan imbauan pesan rasional agar pembaca bisa lebih sadar akan kesalahankesalahan yang terjadi yang terkadang tidak disadari, sementara imbauan pesan emosional dimaksudkan menyentuh perasaan pembaca.

Ada beberapa saran yang akan disampaikan penulis dalam rangka pengembanggan pesan dakwah melalui buku cerita humor khususnya buku "Dari Canda Nabi \& Sufi Sampai Kelucuan Kita" untuk pengarang, pembaca, dan semua civitas akademika Fakultas Dakwah dan Ilmu Komunikasi yaitu:

Pertama, kepada para pengarang untuk tidak ragu dalam membuahkan karya yang bernuasa Islam dan mempublikasikannya secara luas karena itu merupakan bagian dari dakwah yang mulia.

Kedua, kepada para pembaca untuk memahami dan menelaah maksud yang disampaikan oleh pengarang. Sering kali buku humor memberikan pesan tersembunyi. Perlu dihindari memandang sebelah mata akan ajaran Agama Islam dalam suatu buku.

Ketiga, kepada semua civitas akademika Fakultas Dakwah dan Ilmu Komunikasi, teruskan perjuangan dan semoga bisa menjadi insan yang berpendidikan tinggi, berpengetahuan luas, serta diiringi dengan akhlak yang baik. Bisa berguna bagi Negara Indonesia maupun Agama Islam.

\section{DAFTAR PUSTAKA}

Aziz, A. (2009). Ilmu Dakwah. Jakarta: Prenada Media Group.

Bisri, A. M. (2016). Dari Canda Nabi dan Sufi Sampai Kelucuan Kita. Rembang: CV. MataAir Indonesia. 
Departemen Agama Republik Indonesia. (2004). Al-Quran dan Terjemahnya. Bandung: Diponegoro.

Enjang AS dan Aliyudin. (2009). Dasar-dasar Ilmu Dakwah. Bandung: Widya Padjajaran.

Ilaihi, W. (2010). Komunikasi Dakwah. Bandung: Remaja Rosakarya.

Kusnawan, A. (2016). Teknik Menulis Dakwah. Bandung: Simbiosa Rekatama Media.

Rahmanadji, D. 2007 Sejarah, Teori, Jenis dan Fungsi Humor. Jurnal Bahasa dan seni. 213-221

Rakhmat, J. (1998). Islam Aktual. Bandung: Mizan.

Rakhmat, J. (2012). Psikologi Komunikasi. Bandung: Remaja Rosakarya.

Rasjid. (2011). Fiqih Islam (Hukum Fiqib Islam). Bandung: Sinar Baru Algensindo.

Ridwan, A. (2010). Humor dalam Tablig Sisipan yang Sarat Estetika dalam Ilmu Dakwah: Academic Journal for Homiletic Studies, 4(15), 921-956

Ridwan, A. (2013). Stand Up Comedy Ala Santri, Arsyad Press, Bandung.

Tajiri, H. (2015). Etika Dan Estetika Dakwah Perspektik Teologis, Filosofis, dan Praktis. Bandung: Simbiosa Rekatama Media.

Taufik, M. T. (2013). Dakwah Era Digital e-book. Kuningan: Pustaka AlIkhlash. 